\title{
Survivor Syndrome: Effects on Middle Managers in South Africa
}

\section{$\mathbf{R}$ Wiesner}

Department of Human Resource Management and Employment Relations, University of Southern Queensland

\section{P Vermeulen}

Department of Human Resource Management, University of Pretoria

C R Littler

Department of Human Resource Management, Queensland University of Technology

\section{ABSTRACT}

The impact of organisational downsizing on employees who remain has been the subject of intense research, particularly in the USA. The issue of so-called survivor syndrome is critically important in relation to productivity growth and the success of restructuring. However, current conceptualisation has been based largely on American research. There has been little data on downsizing in the South African context. The purpose of this article is to discuss the extent of survivor syndrome in organisations that have restructured and downsized in South Africa. We ask the questions: does downsizing inevitably result in high levels of survivor syndrome; which factors intensify and modify survivor syndrome; and is there a restructuring cycle? The database constitutes 421 South African organisations.

JEL M 12

\section{INTRODUCTION}

The increasing number of articles on the "best" ways to downsize an organisation, suggest a growing realisation that mismanaged reductions in the organisational workforce can have substantial negative consequences amongst the remaining workers (Brockner, 1992; Caudron, 1996; Beam \& Pine, 1992; Boroson \& Burgess, 1992; DBM Australia, 1995; Moskal, 1992; and White, 1996). These employees generally experience a "downsizing survivor syndrome".

The downsizing survivor syndrome is a subject of extensive international economic and social debate. However, it has been based largely on American research and data. There has been little data from other countries, including 
South Africa. An international research team attempted to bridge this gap, and this paper reports some initial findings. After conducting a national survey, a database of 421 organisations across manufacturing and services was constructed for both the public and private sectors of the South African economy.

What is the restructuring trend in South Africa? Sixty percent of the South African respondents indicated that they had been involved in downsizing during 1994 to 1996. What about the frequency of downsizing? Our prior case study data in Australia and New Zealand showed that the frequency of downsizing is a key factor in causing negative worker reaction. The South African data showed that $57 \%$ of the organisations surveyed had downsized twice or more over the two-year period 1995-1996. Many more South African firms are in the first stages of restructuring. However, in 1996 (at the time of the national survey) there was no sign of the process letting up - $44 \%$ of South African managers expected the restructuring cycle to continue for the next two years. It seems that the South African economy is still in the midst of a downsizing cycle today.

Given the above snapshot observations, what have been the effects of downsizing? Much of the research in this area is organised around the notion of "survivor syndrome". This is the focus of the present article too. The two major research questions we address in this article are:

- What is the impact of downsizing on South African middle managers?

- What factors intensify and modify the survivor syndrome?

In defining the limits of this study, it should be noted that the unit of analysis was the organisation, not the individual employee. Therefore, we asked human resource managers to access a variety of employee attitudinal factors including morale, staff commitment, perceived promotion opportunities, motivation, job satisfaction and concern about job security.

\section{DOWNSIZING SURVIVOR SYNDROME}

What is the "survivor syndrome"? It is normally defined as the set of emotions and behaviours exhibited by employees who remain in the organisation after the process of downsizing. Little attention was paid to the downsizing survivors in organisational research until Joel Brockner and colleagues conducted a series of studies on the subject in the mid-1980s (Brockner et al., 1985, 1986, 1987, $1988 \mathrm{a}, 1988 \mathrm{~b}, 1990 \mathrm{a}, 1990 \mathrm{~b}, 1990 \mathrm{c})$. Prior to this research, the emphasis was on the problems of the downsizing victims - the unemployed. 
Brockner (1988: 215) argued that layoffs engender a variety of psychological states among survivors - guilt, inequity, anger, relief, and job insecurity. Moreover, these psychological states have the potential to affect the survivor's work behaviour and attitude, including level of performance, motivation, job satisfaction and commitment. Such arguments were based on equity and organisational stress theory.

"Management sometimes believes that the surviving employees will be so relieved to still have a job, that they will eagerly get down to business; however, often any relief felt by survivors is overwhelmed by less pleasant emotions of downsizing survivor syndrome" (Rubach, 1995: 25). These feelings encompass guilt, loneliness, depression, plummeting morale, destroyed trust, reduced goodwill to the company, lowered confidence and job insecurity (Caudron, 1996; Littler et al., 1996; Skopp, 1993; Moskal, 1992; Lincoln, 1995; Boroson \& Burgess, 1992; Allan, 1996). Feelings of being powerless and trapped can thus occur, especially if the external job market is bleak when a "doom loop" is established (Moskal, 1992).

The bulk of research on survivor syndrome has been based on the United States experience. The American research has consistently found that the negative effects of downsizing as a strategy, have occurred at the human resource level: low morale, decreased productivity, and the hollowing out of company cultures have been repeatedly reported (e.g. Elmuti \& Kathawala, 1993; Downs, 1995; Van Horn \& Dorris, 1996). Van Horn and Doris (1996: 95) suggest that the American work environment "has become a survival camp where morale, productivity, organizational efficiency and absenteeism have run amuck." The American Management Association (AMA) surveys of managers and workers also show very negative human resource outcomes - morale, commitment, job satisfaction and company loyalty are all down (Filipowski, 1993: 71).

\section{The impact of downsizing on job satisfaction}

Job satisfaction is affected by restructuring, and positive reactions have been recorded in some cases: "We may have more work to do as a result of the cutbacks, but it's much more interesting than before" (Brockner, 1992). However, many others feel role ambiguity and overload (Brockner, 1992; Littler et al., 1996; Morin, 1994; Smith, 1994; Lincoln, 1995). For example, chartered professional accountants are doing more routine bookkeeping and engineers carrying out drafting (Buch \& Aldridge, 1990). This has a very negative impact on the job satisfaction of survivors. Our case study research in Australia and South Africa, also indicate that the negative effects of downsizing on the job satisfaction of survivors far outweigh positive reactions. 


\section{The impact of downsizing on staff motivation and commitment}

As in the case of job satisfaction, Brockner $(1988,1992)$ found that the effects of downsizing on victims are not always negative. Survivors respond very differently, even within the same organisational work group. Feelings of "survivor guilt" can actually lead to increased performance after mild layoffs, among survivors with a strong work ethic, some of whom prefer the resulting greater variety and autonomy (Brockner, 1992: 19). Pre-existing stress levels, closeness to layoff victims and the attitude to the fairness of the layoffs affect the ultimate reaction.

Brockner's research (1992) also led him to conclude that if the survivors had been close to the retrenched workers, then their level of productivity was subsequently often lower, and their commitment and motivation to work lessened, particularly if survivors believed the layoffs had been unfair or if the organisation had been overly generous with retrenchment packages.

Therefore, the way that layoffs are handled is important to survivor commitment (Foulkes, 1980; Brockner, 1988; Morin, 1996). As Caudron (1996: 40) recorded from an interview with Compaq Computer: " if survivors knew we were helping their friends who were leaving the company, they would feel more positive about downsizing". Lowered commitment was also shown by Lincoln (1995), Smith (1994) and Burke (1991). However, conflicting with the evidence of negative reactions to downsizing, is the following comment recorded by Brockner (1992): "I feel that some people had to be let go, but frankly, like the organisation, they will probably be better off for it over the longer haul."

On the other hand, conflicting emotions and increased workloads, often without training for those new to areas of control, lead to rise in the stress levels felt by survivors, which often leads to lower productivity (Morin, 1994; Rubach, 1995; Steward, 1992; Buch \& Aldridge, 1990). Littler et al. (1996: 9) coined the phrase "anxiety intensification through downsizing (AIDS)" in comparing the process to disease.

In addition, Grossman (1996), Kozlowski et al. (1993) and Hamilton (1996) all contend that a grieving period is essential after downsizing, in order for survivors to move forward and overcome feelings of guilt, and rebuild the spirit within the workforce - for without this spirit the long-term regeneration and rebuilding of the organisation cannot happen. "Future restructuring cannot work if the co-operation and commitment factor is awaiting the last rites. Innovation, adaptability, flexibility will all show a decline" (Littler et al., 1996: 10). Sundram (1996) and Pearlstein (1996) claim that downsizing has robbed 
companies of the spirit of their workforce and has loosened the bond between workers and employers.

\section{The impact of downsizing on the concern about job security}

Increased feelings of job insecurity seem to be universally experienced by the survivors (Allen, 1996; Burke, 1991; Caudron, 1995; Foulkes, 1980; Skopp, 1993; Boroson \& Burgess, 1992; Moskal, 1992), particularly if layoffs are mismanaged and the changes represent threats rather than opportunities (Brockner, 1992). Insecurity is also heightened if there is multiple downsizing over a period of time, and people remain in the state of "fearful expectancy" (Buck \& Aldridge, 1990), not knowing "when the rain is going to stop" (Smith, 1994: 44). Burke (1991) found the effects of job insecurity to be similar to job loss itself, and Caudron (1996: 39) found that it could even overwhelm the relief of retaining one's job. However, Brockner (1992: 15) also found that survivors might not necessarily feel insecure if there are considerable job opportunities in the labour market.

In a repeated study, Dekker (1995) found that, contrary to expectations, neither support from colleagues, nor management, nor unions seem to protect job incumbents from negative effects. Withdrawal from the job and the organisation, as well as symptoms of psychological stress and burnout may follow. The issue of job security is affected by the notion of a changing psychological contract. A number of writers, for example Morin (1994) and Caudron (1995), indicate that there is a significant change from a psychological contract which involves elements of job security to one which involves "employability". We do not discuss issues pertaining to a change in the psychological contract in this paper. However, see Littler, Bramble \& Mc Donald, 1994.

\section{The impact of downsizing on staff morale}

Survivors are often ignored before, during and after the restructuring process, yet it is they who will be the linchpins of future profitability. They are the ones counted on to make decisions and competently execute their jobs. Unfortunately, survivors are typically an afterthought, as management is so accustomed to thinking of whom to let go and when to do it, that little thought is given to the emotional workplace needs of the survivors (Moskal, 1992: 14). A big risk in downsizing is that it will do nothing to change the way people work; there will be fewer employees who must simply work harder (Allen, 1996). The result may well be a disparate group of hardened cynics (Lincoln, 1995) that will be overworked and burnt out. Productivity often stays the same or deteriorates (Lincoln, 1995) and the company may end up hiring the labour back. 
Frank (1996) questioned the very nature of downsizing, claiming that the resulting fall in morale would cause reduced productivity and an increasing need for overtime. Thus, initial short term gain does not always result in long term profit.

\section{The impact of downsizing on perceived promotion opportunities}

The final attitudinal parameter to be analysed in this paper is the survivors' feelings towards their future promotion opportunities (career path). Downsizing processes often occur in tandem with delayering (see Littler, Bramble \& McDonald, 1994). Boroson and Burgess (1992: 43) found that downsizing caused an increase in job search activity and acceptance of new jobs. Changed career paths, reduction of confidence in upward mobility and diminished career expectations were common occurrences (Buch \& Aldridge, 1990; Skopp, 1993). The consultants Drake Beam Morin (DBM) Australia (1995), conclude that organisations which support and encourage employees in the development of career management skills, will make the effects of further restructuring less traumatic and less costly for both the organisation and the individual. With the current extensive organisational restructuring, career plateaus will appear earlier and in greater proportion than before (Tremblay, Roger \& Toulouse, 1995).

\section{METHODOLOGY}

The primary purpose of the investigation was to obtain national empirical data on downsizing. The survey method was used to obtain the data. A questionnaire was developed by Littler et al. (1996) to measure downsizing and delayering in organisations. This questionnaire was first used in Australia and New Zealand, and then standardised for the South African study. The questionnaire consists of five sections applicable to the organisation, staff numbers, structure and responsibilities of line managers, workforce reduction (including the impact of downsizing on employees), delayering and demographics.

Despite the widespread use of the term "survivor syndrome", it has not been adequately or operationally defined. We have defined it in terms of six key Human Resource Management variables. Respondents were asked to assess these items according to three categories: increased, decreased, unchanged, plus don't know if they were unable to decide. These items were then used to generate an interval scale of "survivor syndrome" scoring 0 to indicate "no survivor syndrome" up to 6 for the worst kind of survivor syndrome (see Table $l$ in the next section). 
The six key Human Resource Management variables are job dissatisfaction, staff motivation, staff commitment, morale among staff, concern about job security and perceived promotion opportunities. These factors were used consistently across the survey questions in relation to the workforce in general. Other factors could have been incorporated, such as stress levels, but we wished to keep the construct as simple as possible and avoid problems of weak convergent validity. The work of Brockner et al. (1985), Greenhalgh and Jick (1989), and Cameron et al. (1993) suggests that the above factors are common across a range of studies and should have convergent validity. In addition, analysis of our case survey data (not reported here) also indicated high convergent validity.

It should be noted that we asked human resource managers about their perceptions of employee morale and other factors. The data are therefore not based on employee self-reports. However, it is reasonable to assume that if any bias occurred, the human resource managers would under-report employee downturns in morale and commitment. This lends even more weight to our findings.

The modus operandi of the sampling in this study was to obtain a broad crosssection of larger organisations throughout South Africa employing 50 or more people, and our sample is thus skewed towards these organisations. This size parameter was chosen because of the primary focus on downsizing and delayering. Therefore, we constructed a three-part sample: all organisations, organisations which had downsized, and organisations which had delayered. There was a significant overlap between the latter two samples.

The time frame of administering the questionnaire has some relevance because of certain minor variations. The questionnaire was administered in South Africa in May 1996, and as several questions refer to "the past two years", it should be noted that this means the period 1994-1996.

\section{Sampling frame}

It was reasoned that staff working in the human resources area of organisations, would have a perspective on restructuring that is reasonably well informed and more detached than line managers who may be directly affected by such organisational change. The sampling frame was derived from the professional register obtained from the South African Board for Personnel Practice. One thousand two hundred names were randomly picked from the register, and the sample represents more organisations than those noted on the Johannesburg Stock Exchange. A questionnaire, accompanied with a covering letter, was mailed to each member of the sample. A reminder and an additional copy of the 
questionnaire were sent to approximately five hundred organisations six weeks after the initial mailing. Of the questionnaires originally sent out, 421 responses were received, which represented a rate of $35.08 \%$. Of the 421 questionnaires sent back, 17 were spoiled and 22 returned unopened or unanswered.

\section{Statistical analysis}

For the purpose of this paper, descriptive statistics were employed in order to demonstrate comparative trends in the data.

In addition, we constructed the "negative-survivor-syndrome-scale" index as a measure of "survivor syndrome" in the three countries and across organisations. This consisted of six items (job dissatisfaction, staff motivation, staff commitment, morale among staff, concern about job security and perceived promotion opportunities) which research has shown to have significant convergence in a downsizing context. These items were added into a single score ranging from 0 to 6 . The index is unweighted, so that the composite score is a sum of the multiple indicators. At the lower end $(0,1)$ the score indicates low survivor syndrome. At the upper end $(6,5)$ the score indicates worrisome levels of survivor syndrome. It is important to appreciate that we are for example not measuring "morale", directly. The causal linkage to downsizing arises from the nature of the question ("Consider the effects of workforce reduction over the past two years on staff generally in your organisation. Please indicate for each \{of the above factors\} whether they have increased, decreased or remained unchanged.")

\section{Overall research methodology}

In addition to the survey data we conducted a number of interviews in South Africa to examine the long-term effects of downsizing and delayering. We do not attempt to present the latter data here, but it affects some of the conclusions drawn from the cross-sectional data.

\section{RESULTS}

What have been the results of this restructuring and downsizing and, given the US data on the effects of downsizing, how does the South African experience feature? At the macro level, there had been a period of economic growth and labour productivity had improved. For example, SA Breweries, the largest employer in South Africa (110 100 workers), improved its turnover per employee by $14 \%$ over a five year period (Financial Mail, 1996). However, the results of this research confirm that restructuring cannot be seen exclusively in 
economic terms. Restructuring in general, and downsizing in particular, have the potential to create new obstacles to sustained profitability and growth. The comparative frequency distributions of the "negative-survivor-syndrome" are summarised in Table 1.

Table 1 Comparative frequency distributions of the "negative-survivorsyndrome-scale"

\begin{tabular}{|c|c|}
\hline Value on scale & $\begin{array}{c}\text { South Africa }(\mathbf{N}=\mathbf{2 2 9}) \\
\mathbf{f}(\%)\end{array}$ \\
\hline 0 & $21(9.2)$ \\
\hline 1 & $29(12.7)$ \\
\hline 2 & $10(4.4)$ \\
\hline 3 & $19(8.3)$ \\
\hline 4 & $41(17.9)$ \\
\hline 5 & $61(26.6)$ \\
\hline 6 & $48(21)$ \\
\hline
\end{tabular}

Scale: the lowest value $0=$ no survivor syndrome and the highest value $6=$ the worst survivor syndrome outcome.

The survey results showed that South African organisations have been affected in a negative way by the effects of downsizing (see tables 1 and 2). The mean response on the "negative-survivor-syndrome-scale" is 3.768 with a standard deviation of 1.9832 .

Tables 1 and 2 confirm that South Africa suffers from a bad case of survivor syndrome. Both tables are impact measures of downsizing on surviving employees. For example, Table 1 shows that $21 \%$ (48) of South African organisations had maximum "survivor syndrome" scores. The distribution is clearly skewed towards significantly negative impacts. Sixty five percent of organisations scored more than 3 on the 6 point scale, $47.6 \%$ scored 5 or 6 , while only $9.2 \%$ of organisations had a zero impact scores. 


\section{Table 2 Survivor syndrome in South Africa}

\begin{tabular}{|l|c|c|}
\hline Human Resource Management variables & $\begin{array}{c}\text { Increase } \\
(\boldsymbol{\%})\end{array}$ & $\begin{array}{c}\text { Decrease } \\
(\boldsymbol{\%})\end{array}$ \\
\hline Morale & $9.2 \%$ & $75.4 \%$ \\
\hline Staff Commitment & $13.8 \%$ & $68.8 \%$ \\
\hline Perceived Promotion Opportunities & $35.2 \%$ & $43.2 \%$ \\
\hline Motivation & $12.6 \%$ & $70.8 \%$ \\
\hline Job Dissatisfaction & $48.6 \%$ & $20.8 \%$ \\
\hline Concern about Job Security & $80 \%$ & $7.6 \%$ \\
\hline
\end{tabular}

Table 2 summarises effects of downsizing on morale, staff commitment, perceived promotion opportunities, motivation, job dissatisfaction and concern about job security.

According to Table 2, employee morale fell in $75.4 \%$ of cases, commitment decreased in $68.8 \%$ of cases, and motivation decreased in $70 \%$ of cases, while concern about job security rose in $80 \%$ of cases. Perceived promotion opportunities is against the trends in Table 2.

In some ways these results are not surprising, because part of the mix of downsizing and restructuring in South Africa, has been the change in political climate. That is, the end of apartheid and a policy of affirmative action have given black South Africans a foothold on the organisational career ladder.

Due to affirmative action, many competent black managers find themselves in an enviable position with regard to promotion. Many white managers however find themselves more on a career plateau with restricted future opportunities. This policy of affirmative action is said to explain the moderated effect of downsizing on promotions in South Africa. The following written comment by a white male respondent summarises the perception: "Affirmative action has resulted in many people skipping the normal promotional steps. This has led to a decreased perception of promotional opportunities by especially white people, and inefficiency caused by delays, while they (the new managers) learn the job and often learn by their mistakes. The latter has led to a high level of frustration on the part of many colleagues. Stress levels has increased enormously",

However, affirmative action and empowerment of at least some black people do not explain the whole South African picture. Slashing and cutting jobs is easy. Managing the results is not. Middle managers who have survived the period of restructuring are now struggling with far greater levels of responsibility, spans of control and workloads. Eighty three percent of firms thought the workloads of 
middle managers had significantly increased during the past two years (Littler \& Wiesner, 1996). What do these greater work pressures amount to? In one word - burnout. Surrounding these pressures is the insecurity of "job today gone tomorrow."

South African job insecurity has not been helped by the extent and depth of the public sector restructuring: 300000 public service jobs were to be shed in three years (Pretoria News, 1996). Headlines like "Public servants in panic over an uncertain future" (Pretoria News, 1996: 19) appear regularly, boosted by statements by politicians like "no public servant should feel ensured of a job in the public service in three years time" (Pretoria News, 1992). Large firms in the private sector also continue to diminish (Financial Review, 1996: 48). The South African downsizing issue cuts across both economic sectors. The figures in Table 2 reflect a scene of managers in crisis as restructuring erodes old securities. Though there are idiosyncratic factors (such as affirmative action policy effects), the data suggest a consistent pattern which confirm the negative effects of downsizing on worker behaviour.

\section{DISCUSSION}

The downsizing literature also suggests that depth of cutting (10\% versus $20 \%$ for example) is an important factor in causing negative worker reaction. For example, Brockner (1988: 230-31) found that layoff severity was negatively associated with organisational commitment. This notion has been expanded to a more complex explanation by some researchers. For example, Hermann (1969) found that worker reactions to cutbacks depend on what he called time pressure dimensions. Two of these dimensions are "forewarning information" and "clarity". Forewarning information refers to advance notice to the effect that cutbacks will occur and when this will take place. Clarity is defined as the degree of ambiguity of the information associated with the expected events. Jick (1985: 93) hypothesised that the less forewarning information and clarity there was, "the higher the likelihood of experienced stress/uncertainty when the cuts finally occur." This hypothesis is strongly supported by existing literature (see for example Shaw, 1994: 18-19). Jick and Murray (1982) combined all of these factors and used the expression "big bomb" to describe a situation of little forewarning and lack of clear-cut information, associated with cutbacks of great severity (i.e. deep job cuts) and time pressure.

The depth of job cutting may not be the key factor in survivor syndrome outcomes. The critical factor is the frequency of cutting, related to a sense that management knows what it is doing. As mentioned in the Introduction, $57 \%$ of the South African organisations had downsized twice or more over the two-year 
period 1995-1996. Repeated reductions undermine the morale of remaining employees and their confidence in management's leadership and direction.

One way of conceptualising this, is to build on Jick's work and make frequency a key factor, as indicated in Figure 1. This suggests that survivor syndrome outcomes are intensified or modified by the depth of workforce reductions ("severity"), time pressure ("forewarning information" and "clarity") and the frequency of downsizing. Implicit in this type of explanation is that the quality of change management at the organisational level has not been very effective in South Africa. Our conclusion on this can only be tentative, but it is indicative nonetheless.

Figure 1 A Typology of Downsizing Situations

\begin{tabular}{|c|c|c|c|c|}
\hline & High & Low & \multirow[b]{2}{*}{$\begin{array}{l}\text { One-off } \longrightarrow \\
\text { Downsizing }\end{array}$} & \multirow[b]{2}{*}{$\begin{array}{l}\text { Leaves set of } \\
\text { effects as } \\
\text { indicated }\end{array}$} \\
\hline High & $\begin{array}{l}\text { Unanticipated } \\
\text { major cuts } \\
\text { "Big bomb" } \\
\text { effect } \\
\text { High stress }\end{array}$ & $\begin{array}{l}\text { Anticipated major } \\
\text { cuts } \\
\text { "Time Bomb" } \\
\text { effect } \\
\text { High to moderate } \\
\text { stress depending } \\
\text { on management }\end{array}$ & & \\
\hline Low & $\begin{array}{l}\text { Unanticipated } \\
\text { minor cuts } \\
\text { "Short-fused } \\
\text { Firecracker" } \\
\text { effect } \\
\text { Moderate } \\
\text { stress }\end{array}$ & $\begin{array}{l}\text { Anticipated minor } \\
\text { cuts } \\
\text { "Long-fused } \\
\text { firecracker" } \\
\text { effect } \\
\text { Low stress }\end{array}$ & $\begin{array}{l}\text { Repeated } \longrightarrow \\
\text { Downsizing }\end{array}$ & $\begin{array}{l}\text { Converts all } \\
\text { situations } \\
\text { ("firecrackers } \\
\text { " or "bombs") } \\
\text { into major set } \\
\text { of survivor } \\
\text { syndrome } \\
\text { problems }\end{array}$ \\
\hline
\end{tabular}

Respondents were asked: "Over the past 2 years, how often has your organisation engaged in workforce reduction?" Consequently, high frequency responses are likely to involve a high recency factor. In other words, given the time frame, if you have done it frequently, you are likely to have done it recently. This means that the frequency variable cannot be insulated from some contamination by a recency effect. This is a difficult factor to control for, and requires further longitudinal research.

The recency argument has not been fully articulated in the literature, with the possible exception of the grief model applied to organisational change. But it 
often functions implicitly. Downsizing and restructuring cause considerable problems, at both personal and structural levels. People often resist change. However, in time the situation "cools off", people adapt and "grief" problems are finally resolved by acceptance. Labour turnover will increase. Many people will leave the organisation, especially those who are most dissatisfied.

Therefore, underlying both the frequency correlations and the restructuring cycle may be recency effects. South Africa started extensive downsizing and restructuring only in 1993-1994, although some restructuring efforts date as far back as the late 1980 s. Our case study and survey results indicate that survivor syndrome outcomes are extremely negative in South Africa. The negative impact of downsizing was still fresh in respondents' minds at the time of the survey and it was obvious that the situation had not "cooled off", people had not yet adapted and the "grief" problems had not been resolved by a final stage of acceptance. In a duplicate study in New Zealand, the situation proved much more positive than in South Africa. However, the respondents in that study had gone through downsizing much earlier and the situation seemed to have "cooled off" by the time of survey. This implies that a restructuring cycle involving a "cooling down" survivor syndrome process is a reality. However, it is possible that frequency of downsizing has an independent effect on the survivors.

If a restructuring cycle does exist, then it is important to conceptualise this explicitly. So far, this has not been done in the literature. It should be underlined that we are not referring to a business cycle here. A restructuring cycle is a set of organisational processes involving significant attitudinal shifts by the workforce within a specific time frame, associated with changing organisational structures and downsizing. In particular, such factors as organisational commitment, motivation and concern about job security, seem to be critical. The process of change in such factors is significant in relation to productivity growth, and the success or failure of organisational restructuring.

\section{CONCLUSIONS}

Our concern was to investigate the impact of downsizing on survivors. In this article we have presented some of our initial results. It is evident from the results that the impact of downsizing has hit South African managers hard.

The corporate strategy of downsizing can be seen as the modern equivalent of a Schumpeterian process of creative destruction, such that downsizing will never end (Maurer, 1996). Opposed to this linear view is the notion of a restructuring cycle. 
Until recently, few voices were raised against downsizing as a corporate strategy. However, as disenchantment with downsizing as a strategy has spread in the USA, it has been taken up as restructuring strategy in several other economies. The paradox is that many US firms are now expressing misgivings about the principle of downsizing. This partly relates to the widespread phenomenon of the survivor syndrome in America. Such a phenomenon implies that the objectives of downsizing and organisational restructuring are often contradictory (URCOT, 1996: 1). Downsizing on its own, can minimise or negate any productivity improvement sought from a leaner workforce and job redesign.

Downsizing can work. It is not always the wrong decision, but nor is it a substitute for a comprehensive restructuring strategy. Organisations cannot simply downsize their way to excellence. An addiction to repeated job cuts leads to the collapse of morale, hollowing out, and nipping a possible recovery in the bud. The USA has been undergoing a downsizing cycle since the early $1980 \mathrm{~s}$ and, perhaps, that cycle is nearing its end. Hence the debate rhetoric is now shifting in the USA (AMA, 1997). South Africans are however still living with the cycles of downsizing and dislocation.

\section{ENDNOTE}

This paper is part of a broader project on organisational restructuring, downsizing, delayering and management labour markets, co-ordinated by Professor Craig R. Littler (Queensland University of Technology) in conjunction with Dr. Retha Wiesner (University of Southern Queensland), Professor Richard Dunford (Victoria University of Wellington), Dr. Tom Bramble (University of Queensland), and Professor Leo Vermeulen (University of Pretoria). Professor Andrew Hede's (Sunshine Coast University College) input and initiative have been invaluable.

\section{REFERENCES}

1 ALLEN, E. (1996) "Dodging the Downsizers", Working Woman, May: 65-6.

2 AMA (1997) "Job Cuts, Downsizing Tumble as Major U.S. Firms opt for Growth", Internet http:/www.amanet.org/survey/pr97survey.htm: 1-3.

3 AUSTIN, N.K. (1995) "Managers Employing Post Re-Engineering", Working Woman, January: 20-22.

4 BEAM, J. \& PINES, H. (1992) "Working with Survivors of Downsizing", HR Focus, American Management Association, 1-12. 
5 BOROSON, W. \& BURGESS, L. (1992) "Survivors' Syndrome: Across the Board", The Conference Board Magazine, November: 41-5.

6 BROCKNER, J. (1988) "The Effects of Work Layoffs on Survivors: SelfEsteem and Survivor Guilt: Research Theory and Practice", Research in Organisational Behaviour, 10:213-55.

7 BROCKNER, J. (1992) "Managing the Effects of Layoffs on Survivors", California Management Review, 34(2): 9-28.

8 BROCKNER, J., DAVEY, J. and CARTER, C. (1985) "Layoffs, SelfEsteem and Survivor Guilt: Motivational, Affective, and Attitudinal Consequences", Organizational Behaviour and Human Decision Processes, 16: 229-44.

9 BROCKNER, J., DEWITT, R., GROVER, S. and REED, T. (1990a) "When it is Especially Important to Explain Why: Factors Affecting the Relationship between Managers' Explanations of a Layoff and Survivors' Reactions to the Layoff", Journal of Experimental Social Psychology, 26: 389-407.

10 BROCKNER, J., GREENBERG, J., BROCKNER, A., BORTZ, J., DAVY, J. and CARTER, C. (1986) "Layoffs, Equity Theory and Work Motivation: Further Evidence for the Impact of Survivor Guilt", Academy of Management Journal, 29: 373-84.

11 BROCKNER, J., GREENBERG, J., GROVER, S. (1988a), "The Impact of Layoffs on Survivors: Insights from Interpersonal and Organizational Justice Theory", In Advances in Applied Social Psychology, (eds.) J. Carrol, Erlbaum: Business Settings, Hildae, New Jersey: 45-75.

12 BROCKNER, J., GROVER, S. and BLONDER, M. (1988b) "Predictors of Survivors' Job Involvement Following Layoffs: A Field Study", Journal of Applied Psychology, 73 (3): 436-42.

13 BROCKNER, J., GROVER, S., REED, T., DEWITT, R. and O'MALLEY, M. (1987) "Survivors' Reactions to Layoffs: We Get By with a Little Help from our Friends", Administrative Science Quarterly. 32: 526-41.

14 BROCKNER, J., GROVER, S., REED, T., DEWITT, R. and WIESENFELD, B. (1990b) The Effects of Layoffs on Survivors: A Social Influence Analysis, Unpublished manuscript, Columbia University.

15 BROCKNER, J., WIESENFELD, B., REED, T. and GROVER, S. (1990c) Further Determinants of Layoff Survivors' Reactions: The Interactive Effect of Perceived Job Complexity and Perceived Fairness on Organizational Commitment and Turnover Intention, Unpublished Manuscript, Columbia University.

16 BUCH, K. \& ALDRIDGE, J. (1990) "Downsizing Challenges and OC Interventions: A Matching Strategy", Journal of Managerial Psychology, 5(4): 32-7. 
17 BURKE, R. J. (1991) "Job Insecurity in Stockbrokers", Journal of Managerial Psychology, 6(5): 10-16.

18 CAUDRON, S. (1996) "How to Manage Survivor Syndrome", Personnel Journal, 75 (1): 38-48.

19 CAUDRON, S. (1995) "Shell-Shocked Survivors - Reviving Employees after the Downsizing Smoke Clears", Black Enterprise, 52.

20 DRAKE BEAM MORIN AUSTRALIA (1995) "Survey of Retrenched Executives", 2 - 5.

21 DEKKER, S., SCHAUFELI, W. (1995) "The Effects of Job Insecurity on Psychological Health and Withdrawal: A Longitudinal Study", Australian Psychologist, 30 (1): 57-63.

22 DENTON, K.D. (1992) Recruitment, Retention and Employee Relations Field Tested Strategies for the '90s, Quorum Books, Connecticut.

23 DOWNS, A. (1995) Corporate Executions. AMACOM.

24 ELMUTI-D. \& KATHAWALA, Y. (1993) "Rightsizing for Industrial Competitiveness: Important Thoughts to Consider", Business-Forum, 18: 8-11.

25 FILIPOWSKI, D. (1993) "Downsizing isn't Always Rightsizing", Personnel Journal, November: 71.

26 FISHER, C.D. (1989) "Current and Recurrent Challenges in HRM", Journal of Management, 15 (2): 157-80.

27 FOULKES, F.K. (1980) Personnel Policies in Large Non-Union Companies, Prentice-Hall, Englewood-Cliffs: New Jersey.

28 FRANK, ALLAN, D. (1996) "The Hidden Costs of Downsizing", Financial Network CNN, February: 23.

29 GREENHALGH, L. (1982) "Maintaining Organizational Effectiveness during Organizational Retrenchment", Journal of Applied Behavioral Science, 18: 155-70.

30 GROSSMAN, R.J. (1996) "How to Revitalize the workplace", $H R$ Magazine, May: 18-14.

31 HAMILTON, J. (1996) "Reengineering from the Human Perspective", Paper presented at Business Process \& Workflow Conference, February: 7.

32 JICK, T.D. \& MURRAY, V.V. (1982) "The Management of Hard Times: Budget Cutbacks in the Public Sector Organizations", Organization Studies, 3 (2): 141-69.

33 KOZLOWSKI, S.W., CHAO, G.T., SMITH, E.M. and HEDLUND, J. (1993) "Organisational Downsizing: Strategies, Interventions and Research Implications", International Review of Industrial and Organisational Psychology: 8.

34 LANSBURY, R.D. (1992) "Managing Change in a Challenging Environment", Asia Pacific Journal of Human Resources, 30(1): 16-28. 
35 LINCOLN, S. (1995) "Downsizing is Useless without Changes to Work Processes", HR Monthly, 14-15.

36 LITTLER, C.R., BRAMBLE, T. and MCDONALD, J. (1994) "Organisational restructuring: Downsizing, Delayering and Managing Change at Work", Industrial Relations Research Series, 15 (Department of Industrial Relations: Canberra).

37 LITTLER, C.R., BRAMBLE, T. and DUNFORD, R. (1996) "Downsizing - A Disease or a Cure?", HR Monthly, 8-12.

38 LITTLER, C.R. \& WIESNER, R. (1996) "Restructuring in South Africa - Mandela's Managers in Crisis", Financial Review, Opinion page leading article, 6 December.

39 LITTLER, C.R., WIESNER, R. and VERMEULEN, L.P. (1997) "The Effects of Downsizing: Cross-cultural Data from Three Countries", Paper presented at the Academy of Management, Boston, Massachusetts.

40 MAURER, J.S. (1996) "Corporate Restructuring in America", Vital Speeches of the Day, 62(16): 505-8.

41 MORIN, W. (1994) "When the Ties that Bind Break", Training and Development, American Society for Training and Development, Alexandria VA: 157.

42 MOSKAL, B.S. (1992) "Managing Survivors", Industry Week, 3, (15): 1, 241.

43 PEARLSTEIN, S. (1996) "Downsizing's Impact on Jobs begins Showing Up in Studies", The Washington Post.

44 RUBACH, L. (1995) "Downsizing: How Quality is Affected as Companies Shrink", Quality Progress, 28(4): 23-8.

45 SHAW, M.D. (1994). "An Investigation into Strategies for Managing Rightsizing", Master of Business dissertation, University of Central Queensland.

46 SKOPP, J. (1993) "HR Paints a Bleak Portrait of Downsizing Survivors", HR Focus, 80(5): 24.

47 SMITH, L. (1994) "Burned Out Bosses", Fortune, 25, 130(2): 44-9.

48 STEWART, V. (1992) "Human Capital Issues in Organisational Change", Asia Pacific Journal, Vol. 30(1): 57.

49 SUNDRAM, J. (1996) "Change Management and the Emotional Virus", Internet http:/www.webcom.com/hr.../Articles/changemgt.html.

50 URCOT (1996) Downsizing and Organisational Change, Melbourne.

51 VAN HORN, C. \& DORIS, A. (1966) "Perceived Communication Barriers between Management and Support Staff Personnel Undergoing Organisational Restructuring", American Business Review, June: 95-107.

52 WHITE, J. \& LUBLIN, J. (1996) "Some Companies Try to Rebuild Loyalty", Wall Street Journal, September: B1. 